\title{
Floc stability and adhesion of green- fluorescent-protein-marked bacteria to flocs in activated sludge
}

\author{
Ann-Cathrin Olofsson, Anna Zita and Malte Hermansson
}

Department of Cell and Molecular Biology, General and Marine Microbiology, Göteborg University, Box 462, SE-40530 Göteborg, Sweden Author for correspondence: Malte Hermansson. Tel: +4631 7732574. Fax : +46 317732599.
e-mail : Malte.Hermansson@gmm.gu.se
Keywords: bacterial adhesion, green fluorescent protein, activated sludge flocs, wastewater, cell surface hydrophobicity

\begin{abstract}
Wastewater is often treated using the activated sludge process. Flocculation and subsequent sedimentation of flocs are vital steps in this process that have direct influence on the quality of the effluent water from wastewater treatment plants. Since cells that remain free-living will decrease the quality of the effluent water it is important to understand the mechanisms of bacterial adhesion to flocs. The green fluorescent protein (GFP) was used as a cellular marker to study bacterial adhesion to activated sludge flocs in situ in sludge liquor. Cell surface hydrophobicity (CSH) was shown to be an important factor that determined the relative bacterial adhesion potential. High CSH correlated with high numbers of attached cells. However, the absolute adhesion of two test bacteria to different sludge flocs varied and could not be explained by the floc characteristics. Confocal laser scanning microscopy of GFP-marked cells showed their position in the floc matrix in situ. Hydrophobic cells attached not only on the surface but also within the floc, whereas hydrophilic cells did not. This indicates that cells may penetrate the flocs through channels and pores and increase the effective surface, which in turn makes the clarification of the wastewater effluent more efficient. The addition of polymers is common practice in wastewater treatment and was shown to increase bacterial adhesion to the flocs. A decrease in surface tension caused by addition of DMSO decreased adhesion, indicating the detrimental effect of surfactants on flocculation. An understanding of basic bacterial adhesion and aggregation mechanisms is important for the managment and control of biotechnological wastewater treatment.
\end{abstract}

\section{INTRODUCTION}

The activated sludge process is widely used for largescale treatment of wastewater. The treatment process depends on the formation of activated sludge flocs, which are aggregates formed by micro-organisms, mainly bacteria, inorganic particles and exocellular polymers (Forster, 1971; Forster \& Dallas-Newton, 1980; Urbain et al., 1993). Sedimentation of flocs at the

Abbreviations: BATH, bacterial adhesion to hydrocarbons; CLSM, confocal laser scanning microscopy; CSH, cell surface hydrophobicity; ESIC, electrostatic interaction chromatography; GFP, green fluorescent protein; HIC, hydrophobic interaction chromatography; MAC, microsphere adhesion to cells; WWTP, wastewater treatment plant. end of the treatment plant results in removal of material from the effluent and also retains the active biomass in the plant. During sedimentation of flocs, dispersed material, such as bacterial cells and small flocs, will attach to the flocs. This 'secondary clarification' stage is important and results in an effluent of good quality. Flocculation and clarification by settling flocs are often rate-limiting steps in the biotechnological processing of wastewater. These vital steps are obviously based on basic bacterial aggregation and adhesion mechanisms.

The DLVO-theory and the thermodynamic approach are the major theoretical foundations used to describe bacterial adhesion (Absolom et al., 1983; Loosdrecht $e t$ al., 1989; Marshall et al., 1971). Both have been used to explain and predict flocculation and bacterial adhesion 
in aerated activated sludge and anaerobic sludge bed reactors. For instance, floc stability was affected by the ionic strength of the medium in a way that suggests that the interactions between the floc components can be explained by the classical DLVO theory, at least in the range of electrolyte concentrations relevant for wastewater (Zita \& Hermansson, 1994).

The thermodynamic approach considers the surface free energy of the interacting surfaces, whilst electric charges, receptor-ligand and steric interactions are neglected (Absolom et al., 1983; Busscher et al., 1984; Loosdrecht et al., 1989). Adhesion processes are favoured if the free energy of the total system decreases, that is if the change in free energy per unit surface area $\left(\Delta F^{\mathrm{adh}}\right)$ is negative as a result of adhesion. $\Delta F^{\text {adh }}$ can be expressed as $\Delta F^{\mathrm{adh}}=\gamma_{\mathrm{BS}}-\gamma_{\mathrm{BL}}-\gamma_{\mathrm{SL}}$ where $\gamma_{\mathrm{BS}}, \gamma_{\mathrm{BL}}$ and $\gamma_{\mathrm{SL}}$ denote the interfacial tensions of the bacterium-substratum, bacterium-liquid and substratum-liquid interfaces, respectively. Adhesion will be spontaneous if $\gamma_{\mathrm{BS}}$ is lower than the sum of $\gamma_{\mathrm{BL}}$ and $\gamma_{\mathrm{SL}}$. The surface tension of the liquid-vapour interface $\left(\gamma_{\mathrm{LV}}\right)$ is an important parameter in adhesion in wastewater. If $\gamma_{\mathrm{LV}}$ is higher than the corresponding solid-vapour $\left(\gamma_{\mathrm{SV}}\right)$ and bacterial-vapour $\left(\gamma_{\mathrm{BV}}\right)$ surface tensions, a decrease in $\gamma_{\mathrm{LV}}$ reduces both $\gamma_{\mathrm{BL}}$ and $\gamma_{\mathrm{SL}}$, thereby decreasing the 'driving force' of the adhesion (Absolom et al., 1983). However, adhesion will increase with decreasing $\gamma_{\mathrm{LV}}$ if $\gamma_{\mathrm{LV}}$ is lower than $\gamma_{\mathrm{SV}}$ and $\gamma_{\mathrm{BV}}$. Consequently, pollution of influent wastewater by surfactants influences the $\gamma_{\mathrm{LV}}$, which may have a large effect on sedimentation and therefore on the overall treatment processes. Furthermore, it has been shown that $\gamma_{\mathrm{LV}}$ influenced the composition of anaerobic consortia in granular sludge bed reactors, such that lowsurface-energy bacteria formed aggregates during high $\gamma_{\mathrm{LV}}$ and high-surface-energy bacteria adhered better to each other during low $\gamma_{\mathrm{LV}}$ (Thaveesri et al., 1995).

At least from an operational view, hydrophobicity is related (but not equivalent) to the surface wettability, which is commonly used as a measure of the surface free energies used in the thermodynamic approach (DuncanHewitt, 1990). Cell surface hydrophobicity (CSH) is considered an important factor for bacterial adhesion in many different systems (Rosenberg \& Kjelleberg, 1986). Adhesion experiments in wastewater with a series of Escherichia coli strains as well as isolates from wastewater, showed that bacteria with a high $\mathrm{CSH}$ attached in higher numbers to activated sludge flocs than hydrophilic bacteria (Zita \& Hermansson, 1997b). These findings were supported by the results from a recent in situ investigation of CSH of free-living, single cells in wastewater that showed that the majority of these bacteria were hydrophilic (Zita \& Hermansson, 1997a). Furthermore, hydrophobic interactions were suggested to be important in flocculation of aerobic activated sludge (Jorand et al., 1994; Urbain et al., 1993; Valin \& Sutherland, 1982).

In the present work we have used the green fluorescent protein (GFP) (Chalfie et al., 1994) as a bacterial marker to study bacterial adhesion of cells with known surface characteristics to activated sludge flocs in situ in sludge liquor in some detail. Conventional epifluorescence microscopy and confocal laser scanning microscopy (CLSM) were used to detect GFP-marked cells and their exact position in the floc matrix in situ. We tested the effect of key adhesion parameters, such as CSH and $\gamma_{L V}$, on bacterial adhesion to flocs and floc stability. Polymers are often used in wastewater treatment to enhance flocculation. Combined effects of polymer addition and changes in $\gamma_{\mathrm{LV}}$ on bacterial adhesion to flocs were therefore investigated. The importance of bacterial adhesion and aggregation processes for biotechnological wastewater treatment is discussed.

\section{METHODS}

Bacterial strains and culture conditions. E. coli strains 01, 014 and K51 (K. Krogfelt, Statens Seruminstitut, Denmark) and Serratia marcescens (CCUG $130, \mathrm{Nx}^{\mathrm{R}}$ ) were cultivated in Luria broth (LB: tryptone, $10 \mathrm{~g}$; yeast extract, $5 \mathrm{~g} ; \mathrm{NaCl}, 5 \mathrm{~g}$; Milli Q water, $1000 \mathrm{ml} ; \mathrm{pH} 7 \cdot 5$ ) at $30^{\circ} \mathrm{C}$ with shaking. E. coli strains were grown overnight, and $S$. marcescens for $48 \mathrm{~h}$. Ampicillin (Ap; $\left.100 \mu \mathrm{g} \mathrm{m}^{-1}\right)$, or nalidixic acid $(\mathrm{Nx}$; $200 \mu \mathrm{g} \mathrm{ml}^{-1}$ ) and kanamycin ( $\mathrm{Km} ; 100 \mu \mathrm{g} \mathrm{ml}^{-1}$ ), and IPTG $(0.8 \mathrm{mM})$ were added to LB or solidified LB when appropriate. Cells were harvested by centrifugation and washed twice with PBS ( $\mathrm{NaCl}, 8.5 \mathrm{~g} ; \mathrm{Na}_{2} \mathrm{HPO}_{4}, 1.34 \mathrm{~g} ; \mathrm{NaH}_{2} \mathrm{PO}_{4} .2 \mathrm{H}_{2} \mathrm{O}, 0.39 \mathrm{~g}$; Milli Q water, $1000 \mathrm{ml} ; \mathrm{pH} \mathrm{7.5)}$. The cells were then resuspended in PBS or in sterile filtered wastewater and incubated overnight at $30^{\circ} \mathrm{C}$ on a shaker.

GFP-marking of cells. E. coli strains 01,014 and K51 were transformed with pGFP (GenBank accession number U17997; Clontech) using the calcium chloride method (Ausubel et al., 1989). Transconjugants were selected on LB plates with Ap and IPTG. Pseudomonas putida KT 2442 (RP1::gfp) (Andreasen, 1997; Christensen et al., 1997) was conjugated on LB plates with $S$. marcescens overnight at room temperature. Transconjugants were selected on LB plates with $\mathrm{Nx}, \mathrm{Km}$ and IPTG overnight at $37^{\circ} \mathrm{C}$. Green fluorescent transconjugant colonies were picked and stored in glycerol $(50 \%, \mathrm{v} / \mathrm{v})$ at $-80^{\circ} \mathrm{C}$. The number of green fluorescent cells out of the total number of cells was counted each test occasion by combined epifluorescence and phase-contrast microscopy.

Hydrophobic interaction chromatography (HIC) and electrostatic interaction chromatography (ESIC). CSH and cell surface charge were tested by HIC and ESIC, respectively. HIC and ESIC were done as described previously (Hermansson et al., 1982). Briefly, $1 \times 10^{9}$ cells $(1 \mathrm{ml})$ were applied to octyl-Sepharose CL-4B for HIC, and DEAESepharose CL-6B (for negative cell charge) and CM-Sepharose CL-6B ( for positive cell charge) ESIC (Pharmacia), and eluted with $12 \mathrm{ml}$ PBS. Cells $\left(1 \times 10^{9}\right)$ were added to $12 \mathrm{ml} \mathrm{PBS}$ and the initial optical density $\left(\mathrm{OD}_{(1)}\right)$ was measured at $420 \mathrm{~nm}$ (Novaspec, LKB). The optical density of the eluate $\left(\mathrm{OD}_{(\mathrm{e})}\right)$ was also measured. The $\mathrm{CSH}$ or cell surface charge was expressed as $\left(\mathrm{OD}_{(\mathrm{i})}-\mathrm{OD}_{(\mathrm{e})}\right) / \mathrm{OD}_{(\mathrm{e})}$. $\mathrm{HIC}$ was performed on three or more different cultures for all strains and results are presented as mean values. ESIC was done on two or more different cultures and results are presented as mean values.

Microsphere adhesion to cells (MAC). MAC was performed as described previously (Zita \& Hermansson, 1997a). Briefly, hydrophobic fluorescent polystyrene microspheres (diameter, $0 \cdot 1 \mu \mathrm{m}$; FluoSpheres, catalogue no. F-8847, Molecular Probes) were diluted in distilled water to a $10 \%(\mathrm{v} / \mathrm{v})$ solution and sonicated to form a uniformly dispersed solution. Aliquots of 

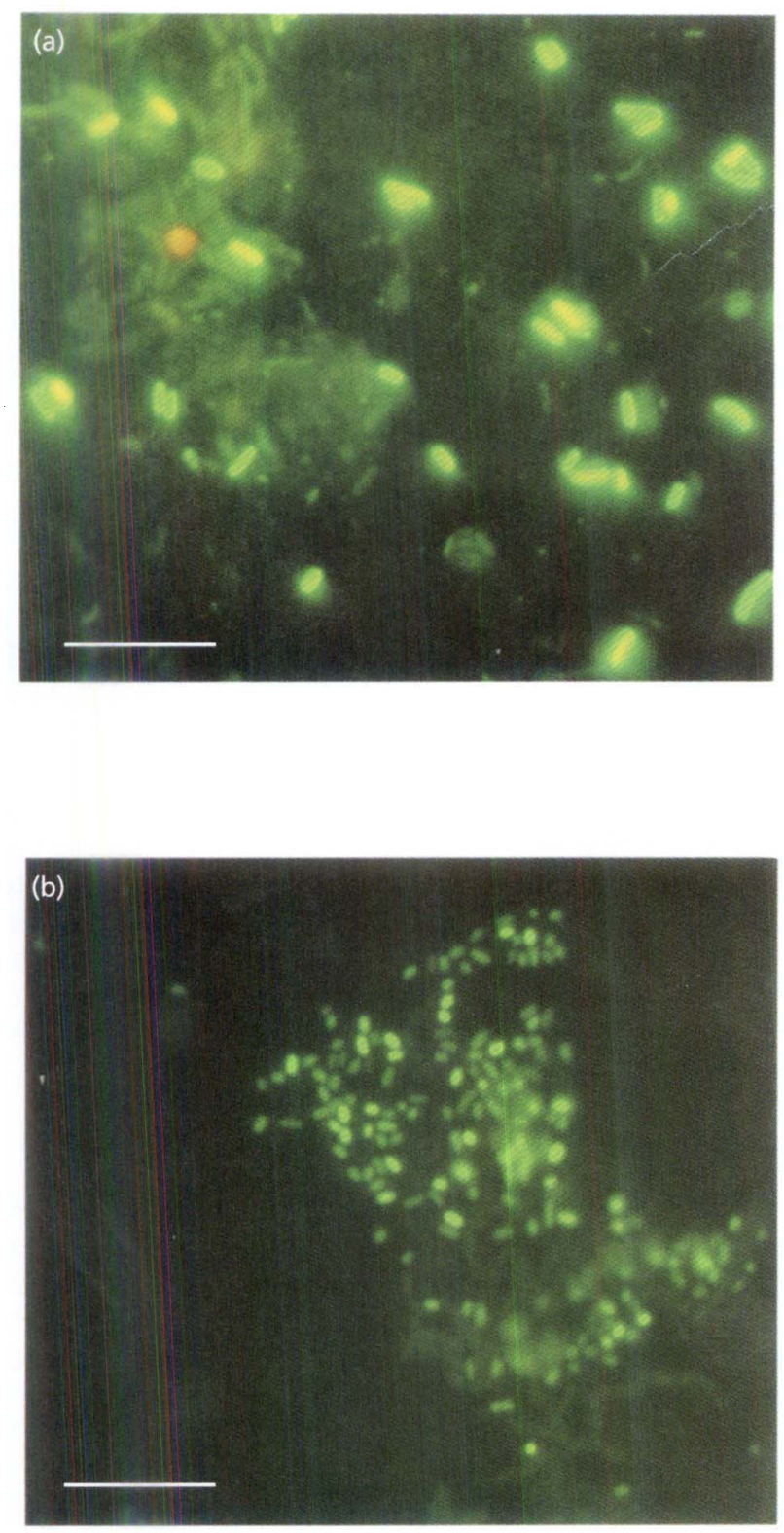

Fig. 1. Epifluorescence micrographs of GFP-marked E. coli 01(a) and $S$. marcescens (b) in sludge suspensions. Bars, $10 \mu \mathrm{m}$.

the microsphere and bacterial solutions $(10 \mu \mathrm{l})$ were added to $0.1 \mathrm{ml}$ distilled water in an Eppendorf tube and vigorously mixed. Three microlitres of the sphere/bacterial solution was removed and $3 \mu \mathrm{l}$ acridine orange $\left(0.1 \mathrm{~g} \mathrm{l}^{-1}\right)$ was added to visualize the bacteria. Bacterial cells $(100-500)$ were examined for attached microspheres by epifluorescence microscopy. The number of spheres per bacterium was counted $(0,1,2,3,4-9$ or $\geqslant 10)$. Hydrophobicity was expressed as the percentage of cells with three or more microspheres or as a frequency distribution of cells carrying different numbers of attached microspheres. A high percentage corresponds to a hydrophobic cell. MAC was tested on two or more bacterial cultures and results are presented as mean values.

Bacterial adhesion to hydrocarbons (BATH). The BATH assay was performed as described previously (Zita \& Hermansson, 1997a). Hydrophobicity was expressed as $[(a-b) / a] \times 100$, where $a$ is the initial cell concentration in the aqueous phase and $b$ is the concentration in the aqueous phase after partitioning. Samples were run in duplicate and for two parallel bacterial cultures, and results are presented as mean values.

Rya wastewater treatment plant (WWTP) sludge characteristics and sampling. Analyses of influent water, activated sludge and effluent water were performed at the Rya WWTP, which receives wastewater from approximately 550000 people and 220000 equivalents of industry, mainly food (fat and milk) and paper pulp. Analyses of solids in suspension ( $\mathrm{SS} ; \mathrm{mg} \mathrm{l}^{-1}$ ), sludge volume (SV; $\mathrm{ml})$, sludge volume index $\left(\mathrm{SVI} ; \mathrm{ml} \mathrm{g}^{-1}\right.$ ) and stirred sludge volume index (SSVI; $\mathrm{ml} \mathrm{g}^{-1}$ ) were done on different sampling occasions. The shape factor of the sludge flocs, $\mathrm{S}$, was defined as $\mathrm{S}=(\mathrm{SQI} / 1 \cdot 16 \mathrm{SSVI})-1$, where $\mathrm{SQI}=$ $(\mathrm{SV} / 3)+200 / \mathrm{SS}$ (Eriksson et al., 1992). The mean temperature value of the effluent water was $19^{\circ} \mathrm{C}$ and the $\mathrm{pH}$ was 7 . Activated sludge was taken from the end of the aeration tank at two points, one before and one after the site where artificial polymer was added to the sludge liquor. Samples were transported to the laboratory for experiments and treated within $2 \mathrm{~h}$.

Adhesion of GFP-marked test bacteria. Based on the HIC results, GFP-marked E. coli 01 and $S$. marcescens were chosen to represent hydrophilic and hydrophobic cells, respectively. Cells were added to scintillation vials containing $10 \mathrm{ml}$ wastewater (final concentration of marked cells $1 \times 10^{7} \mathrm{ml}^{-1}$ ). The added number of cells was about the same as the number of indigenous free-living wastewater bacteria. The vials were incubated on a shaker for 5,15 or $30 \mathrm{~min}$, after which the flocs were allowed to settle for $10 \mathrm{~min}$. Five hundred microlitres of the supernatant was filtrated together with $500 \mu$ l glycerol $(50 \%, \mathrm{v} / \mathrm{v})$ onto a $0.2 \mu \mathrm{m}$ pore-size Nucleopore filter (prestained with Sudan black B) and the filter was mounted on a glass slide with type FF immersion oil (Zeiss). The number of green fluorescent free-living cells (i.e. not associated with flocs) was enumerated in an Olympus epifluorescence microscope at a magnification of $\times 1250$, using blue excitation light (excitation filter B, dichroic mirror B and barrier filter O-530). At least 700 cells were counted for each sample. Adhesion tests were performed on eight different sampling occasions spread over 2 months, and are presented as mean values. Adhesion of GFP-marked bacteria to flocs were also tested in the same way in wastewater with $3 \%$ DMSO. In these experiments, the incubation time was $30 \mathrm{~min}$. The latter experiments were carried out five times.

Half-maximum adhesion time was calculated (from Fig. 4) as the time when half of the maximum cell number had attached, where maximum attachment was defined at $30 \mathrm{~min}$.

CLSM. GFP-marked E. coli 01 and $S$. marcescens were incubated with $10 \mathrm{ml}$ (final cell concentration $1 \times 10^{7}$ cells $\mathrm{ml}^{-1}$ ) wastewater for $30 \mathrm{~min}$ on a shaker, after which larger flocs were allowed to settle for $10 \mathrm{~min}$. Ten microlitres of supernatant was removed and added to $200 \mu \mathrm{l}$ PBS in a glass chamber where flocs were allowed to settle. Flocs and GFPmarked cells were examined directly in the water using an inverted Nikon microscope equipped with a Molecular Dynamics $\mathrm{Ar} / \mathrm{Kr}$ laser at an excitation wavelength of $488 \mathrm{~nm}$. A $488 \mathrm{~nm}$ laser wavelength filter, a 510 DRLP primary beam splitter and a 510 EFLP barrier filter were used. Sequences of images were taken along the optical $(z)$ axis in steps of $0.26 \mu \mathrm{m}$. Scans from 115 to 174 steps were combined to form 
five layers of approximately $30-45 \mu \mathrm{m}$. Image processing including three-dimensional reconstruction was done with ImageSpace software using a Silicon Graphics computer. Images were filtered using $3 \mathrm{D}$ Median $(3 \times 3 \times 3 \mathrm{kernel})$ and the lookthrough projection mode. Images were printed on a CODONICS NP-1600 Photographic Network printer. Several flocs were examined and representative data from the two bacteria are shown.

Floc stability test. Wastewater $(10 \mathrm{ml})$ from different sampling places (influent, aeration-start, aeration-end, recycled sludge and effluent water) was added to scintillation vials. Flocs were incubated with different DMSO concentrations $(0,3,7 \cdot 5,10$ or $15 \%$ ) on a shaker for $30 \mathrm{~min}$ and the flocs were allowed to settle for $10 \mathrm{~min}$. The $\mathrm{OD}_{420}$ of $2 \mathrm{ml}$ supernatant samples was measured. When flocs dissociate the smaller floc fragments and free-living cells remain in the supernatant resulting in an increased optical density. The floc stability test was performed on two sampling occasions and the result from one experiment is shown.

Table 1. Hydrophobicity measured by HIC for $E$. coli K51, 014 and 01 and S. marcescens incubated in PBS

Hydrophobicity is expressed as the ratio between cells retained in the $\mathrm{HIC}$ gel and cells in the eluate, measured as $\mathrm{OD}_{420}$.

Values are means \pm SEM from four to seven experiments.

\begin{tabular}{|lcc|}
\hline Strain & \multicolumn{2}{c|}{ Hydrophobicity } \\
\cline { 2 - 3 } & Wild-type cells & GFP-marked cells \\
\hline E. coli K51 & $0 \cdot 09 \pm 0.005$ & $0 \cdot 17 \pm 0.02$ \\
E. coli 014 & $0.03 \pm 0.01$ & $0 \cdot 04 \pm 0.03$ \\
E. coli 01 & $0.08 \pm 0.02$ & $0 \cdot 10 \pm 0.02$ \\
S. marcescens & $1.08 \pm 0.17$ & $0 \cdot 67 \pm 0 \cdot 10$ \\
\hline
\end{tabular}

* pGFP was used for marking the E. coli K51, 014 and 01 strains, and RP1::gfp was used for $S$. marcescens.

\section{RESULTS}

\section{GFP-marked cells}

Bacteria marked with GFP showed a clear fluorescence under the epifluorescence microscope and could be distinguished in the activated sludge (Fig. 1a, b). While $100 \%$ of the $S$. marcescens cells were fluorescent, about $60 \%$ (mean for all experiments) of the E. coli cells showed fluorescence. The percentage fluorescent cells was checked before each experiment and the number of fluorescent cells was adjusted so as to be the same in all experiments. No effect on the attachment of $E$. coli to the flocs was detected due to this variation in fluorescence (Spearman rank correlation coefficient $\left(r_{\mathrm{s}}\right)$ $-0.6, P=0.2$; and $r_{\mathrm{s}}-0.3, P=0.5$ for percentage GFPmarked E. coli plotted against adhesion to flocs in the presence or absence of polymers, respectively). Also, there was no difference between GFP-marked and wildtype E. coli in their CSH and surface charge (see below, and Tables 1 and 2). We used RP1 in S. marcescens as a vector for $g f p$, in order to achieve stable maintenance of the $g f p$-carrying plasmid and convenient resistance markers. RP1 is stably maintained in $S$. marcescens but has a lower copy number than pGFP (which was used to transform E. coli) and therefore gives a lower fluorescence per cell and a faster fading of the fluorescence compared with $E$. coli. Despite this, $S$. marcescens cells could still be clearly detected in the sludge samples (Fig. 1b).

\section{CSH and cell surface charge}

Initially the hydrophobicity of $S$. marcescens and the $E$. coli strains was measured by HIC (Table 1). S. marcescens showed the highest degree of CSH. The E. coli strains 014, 01 and K51 were all hydrophilic. None of the strains showed a significant change in $\mathrm{CSH}$ after being marked with GFP (Student's $t$-test: $P>0.05$ for all strains). E. coli 01 was chosen together with $S$.

Table 2. Cell surface charge and CSH of GFP-marked E. coli 01 and S. marcescens incubated in PBS and in wastewater (WW)

\begin{tabular}{|c|c|c|c|c|c|c|c|c|c|c|}
\hline \multirow[t]{3}{*}{ Strain } & \multicolumn{4}{|c|}{ Cell surface charge* } & \multicolumn{6}{|c|}{$\mathrm{CSH}+$} \\
\hline & \multicolumn{2}{|c|}{ Negative } & \multicolumn{2}{|c|}{ Positive } & \multicolumn{2}{|c|}{ BATH } & \multicolumn{2}{|c|}{ HIC } & \multicolumn{2}{|c|}{ MAC } \\
\hline & PBS & WW & PBS & WW & PBS & WW & PBS $\neq$ & WW & PBS & WW \\
\hline E. coli 01 & +++ & +++ & + & + & $87 \pm 5 \cdot 7$ & - & $0.08 \pm 0.02$ & $0 \cdot 12 \pm 0 \cdot 03$ & $11 \pm 1 \cdot 2$ & $26 \pm 0.5$ \\
\hline E. coli $01:: g f p$ & ++ & +++ & + & + & $100 \pm 1 \cdot 0$ & - & $0 \cdot 10 \pm 0 \cdot 02$ & - & $12 \pm 1 \cdot 0$ & $24 \pm 19$ \\
\hline S. marcesens & ++ & ++ & + & + & $36 \pm 1 \cdot 0$ & - & $1 \cdot 08 \pm 0 \cdot 17$ & $1 \cdot 6 \pm 0.01$ & $88 \pm 1 \cdot 6$ & $88 \pm 0$ \\
\hline S. marcesens::gfp & ++ & +++ & + & + & $22 \pm 2 \cdot 1$ & - & $0 \cdot 67 \pm 0 \cdot 10$ & - & $89 \pm 2 \cdot 9$ & $86 \pm 0.5$ \\
\hline
\end{tabular}

* Cell surface charge was measured by ESIC and expressed as the ratio between cells retained in the gel and cells in the eluate, measured as $\mathrm{OD}_{420^{\circ}}+, 0-1 ;++, 1-5 ;+++,>5$. The SEM was from 20 to $100 \%$ of the mean for all values.

+BATH values are expressed as the percentage of cells remaining in the water phase; HIC values are expressed as the ratio between cells retained in the gel and cells in the eluate, measured as $\mathrm{OD}_{420} ; \mathrm{MAC}$ values are expressed as the percentage of cells having more than three attached hydrophobic microspheres. All values are means \pm SEM from at least two experiments.

$\neq$ From Table 1. 

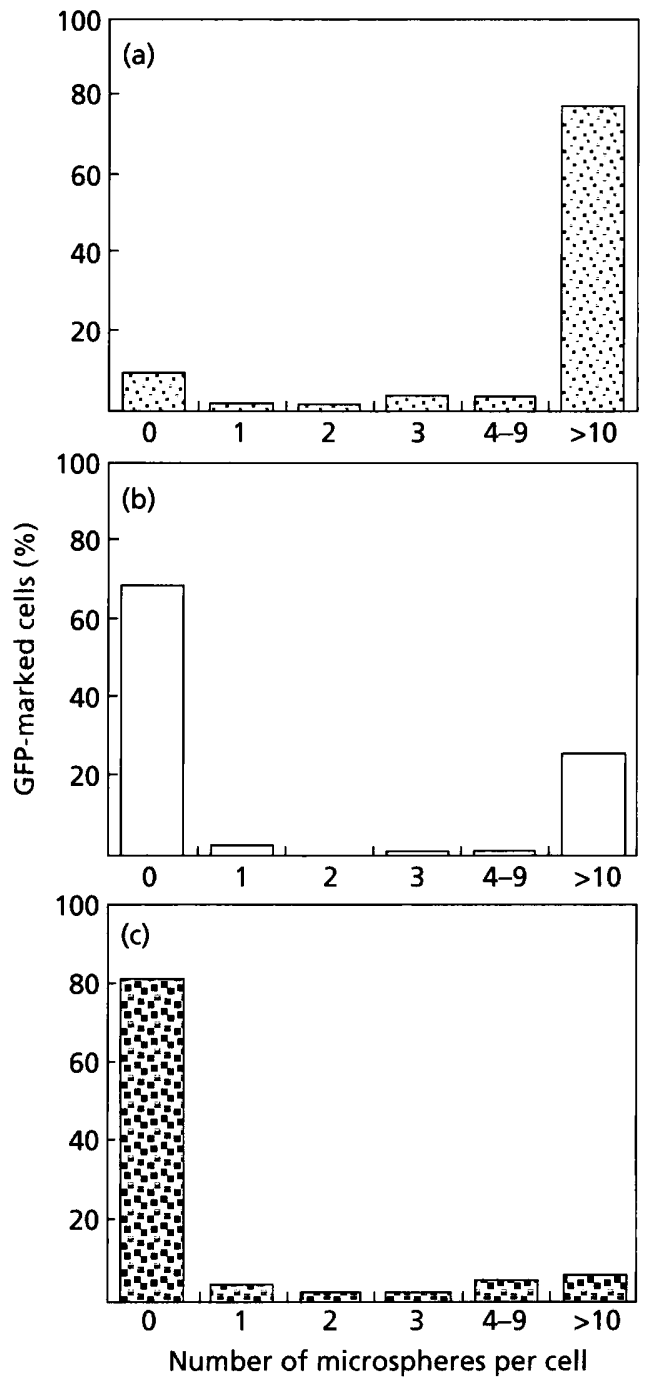

Fig. 2. Frequency distribution of GFP-marked cells with different numbers of attached hydrophobic microspheres (MAC test). (a) S. marcescens in wastewater; (b) $E$. coli 01 in wastewater; (c) E. coli 01 in PBS. For each bacterium, 130-300 cells were analysed.

marcescens for adhesion experiments. The initial CSH tests were done in PBS. CSH of E. coli 01 and $S$. marcescens was further investigated by HIC, BATH and MAC after incubation in PBS or wastewater (Table 2). All three methods showed that $S$. marcescens possessed a more hydrophobic cell surface than E. coli 01 in PBS. These differences generally remained after incubation in wastewater (Table 2). The frequency distribution of hydrophobic cells in populations of GFP-marked $S$. marcescens and E. coli 01 in wastewater is shown in Fig. 2(a, b). It is clear that the $S$. marcescens population had a higher percentage of hydrophobic cells than did the E. coli 01 population. There was also, however, a subfraction of hydrophobic cells within the E. coli 01 population (Fig. 2b). This subfraction was smaller in PBS (Fig. 2c), indicating that part of the population may have changed in wastewater.

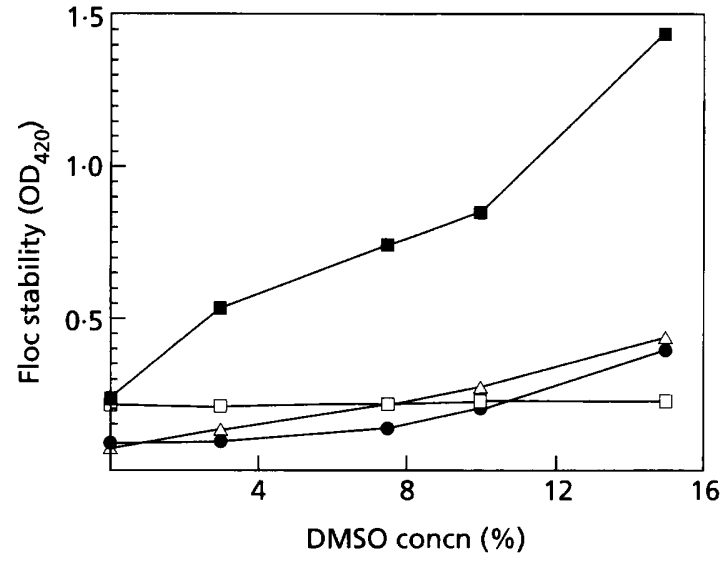

Fig. 3. Floc stability measured as $O D_{420}$ of the supernatant after incubation for $30 \mathrm{~min}$ with shaking in different DMSO concentrations followed by sedimentation for $10 \mathrm{~min}$. Samples were collected from the start of the aeration basin $(\triangle)$, the end of the aeration basin (O), recycled sludge $(\square)$ and influent water $(\square)$. One representative experiment is shown.

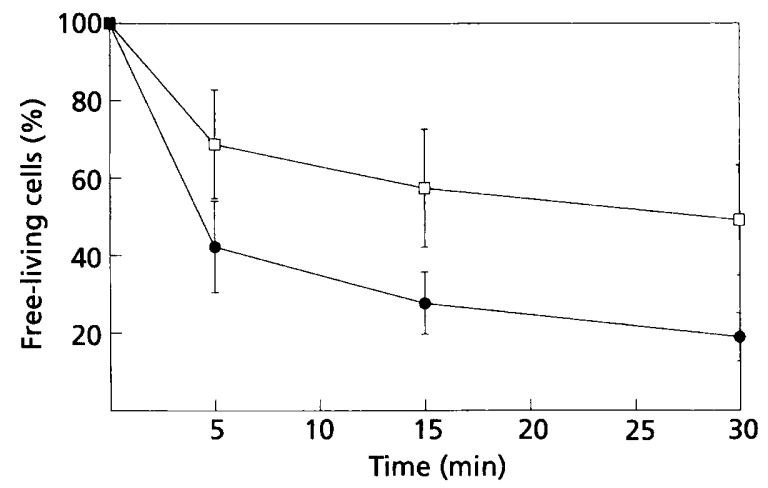

Fig. 4. Percentage free-living E. coli $01(\square)$ and S. marcescens (O) cells remaining in sludge supernatants after 5,15 and $30 \mathrm{~min}$ of sedimentation of the flocs. Samples were taken at a point in the process line before polymer addition. Values are means of five sampling occasions and standard deviations are indicated by bars.

The cell surface charge of $S$. marcescens and E. coli 01 was also measured after incubation in PBS or wastewater (Table 2). Rather high variations in ESIC were seen between cultures (SEM between 40 and $100 \%$ of the mean) and the conclusions that can be drawn are therefore limited. Such variations in ESIC measurements between cultures has been noted previously (Stenström \& Kjelleberg, 1985). Both strains possessed a relatively low number of positive charges on their surfaces as determined by ESIC. There were no large differences between wild-type and GFP-marked cells, nor between cells that were incubated in PBS and in wastewater.

\section{Sludge floc stability}

Except in the influent wastewater, the $\mathrm{OD}_{420}$ of the supernatant increased after DMSO incubation, indi- 
Table 3. Percentage free-living GFP-marked E. coli 01 and S. marcesens cells in the supernatant after 30 min contact with activated sludge, and sludge characteristics

Analysis of influent water, activated sludge and effluent water were performed at the Rya WWTP.

See Methods for further experimental details.

\begin{tabular}{|c|c|c|c|c|c|c|c|}
\hline \multirow{2}{*}{$\begin{array}{l}\text { Sludge } \\
\text { sample }\end{array}$} & \multicolumn{2}{|c|}{ Free-living cells (\%) } & \multicolumn{5}{|c|}{ Sludge characteristics ${ }^{*}$} \\
\hline & E. coli 01 & S. marcesens & $\mathrm{SS}\left(\mathrm{mg} \mathrm{l}^{-1}\right)$ & $\mathrm{SV}(\mathrm{ml})$ & $\mathrm{SVI}\left(\mathrm{ml} \mathrm{g}^{-1}\right)$ & $\operatorname{SSVI}\left(\mathrm{ml} \mathrm{g}^{-1}\right)$ & $\mathrm{S}$ \\
\hline 1 & 17 & 8 & 9 & 750 & 147 & 53 & $3 \cdot 1$ \\
\hline 2 & 66 & 17 & 24 & 800 & 138 & 47 & $4 \cdot 9$ \\
\hline 3 & 33 & 17 & - & 250 & 76 & 62 & 0.2 \\
\hline 4 & 62 & 22 & 18 & 220 & 56 & 60 & $0 \cdot 4$ \\
\hline 5 & 68 & 31 & 11 & 185 & 62 & 42 & $0 \cdot 3$ \\
\hline 6 & 9 & 6 & 17 & 200 & - & 43 & $0 \cdot 3$ \\
\hline 7 & 38 & 22 & 8 & 200 & 57 & 43 & $0 \cdot 3$ \\
\hline 8 & 43 & 24 & - & 215 & 60 & 45 & $0 \cdot 4$ \\
\hline
\end{tabular}

-, Not determined.

* Background data on sludge characteristics are from different sampling occasions. SS, solids in suspension; SV, sludge volume; SVI, sludge volume index; SSVI, stirred sludge volume index; S, shape factor of sludge flocs.

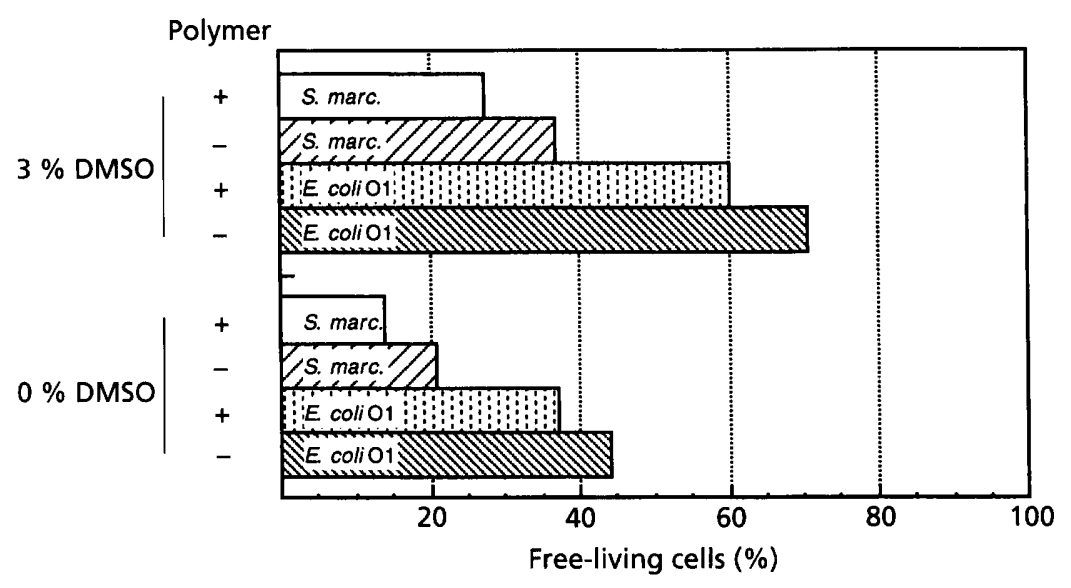

Fig. 5. Percentage free-living bacteria after 30 min contact time with sludge flocs. $E$. coli 01 and S. marcescens were tested with and without DMSO before and after addition of polymers to the wastewater. Values are means of five sampling occasions.

cating that the flocs from most sites of the WWTP decreased in stability when the surface tension $\left(\gamma_{\mathrm{LV}}\right)$ decreased (Fig. 3). At 3\% DMSO the dissociation of flocs was relatively low and this DMSO concentration was chosen for the bacterial adhesion experiments to avoid a large increase in the floc surface that would otherwise have biased the adhesion results.

\section{Free-living cells in sludge suspensions}

The number of free-living E. coli 01 and S. marcescens cells decreased with incubation time in sludge suspensions (Fig. 4). A significantly smaller percentage of the hydrophobic $S$. marcescens cells, compared to E. coli 01 cells, were found in the free-living state (Student's $t$-test : $P<0.005$ ) for all eight sampling occasions (Table 3 ). The sampling occasions were spread over two months with different running conditions, which resulted in different types of sludge flocs. The half- maximum adhesion times were also different, $3.5 \mathrm{~min}$ for $S$. marcescens and $4.1 \mathrm{~min}$ for $E$. coli. The adhesion of the two strains, in absolute terms, varied between sampling occasions. No apparent correlation could be found between adhesion and different sludge characteristics that could explain this variation (Table 3).

Both $E$. coli 01 and $S$. marcescens attached to sludge flocs in significantly higher numbers (Student's $t$-test: $P<0.05$ for both strains) in samples that were taken after polymers were added to the wastewater at Rya WWTP, compared to samples that were taken at a site up-flow from the polymer addition (Fig. 5).

The hydrophobic interactions involved in bacterial adhesion were further investigated by changing the $\gamma_{\mathrm{LV}}$ of the water by adding $3 \%$ DMSO. The number of freeliving cells increased significantly for both strains (Student's $t$-test : $P<0.008$ for both strains) with DMSO, both when the samples were taken before and after the addition of polymers (Fig. 5). No effect on $\mathrm{CSH}$, as 

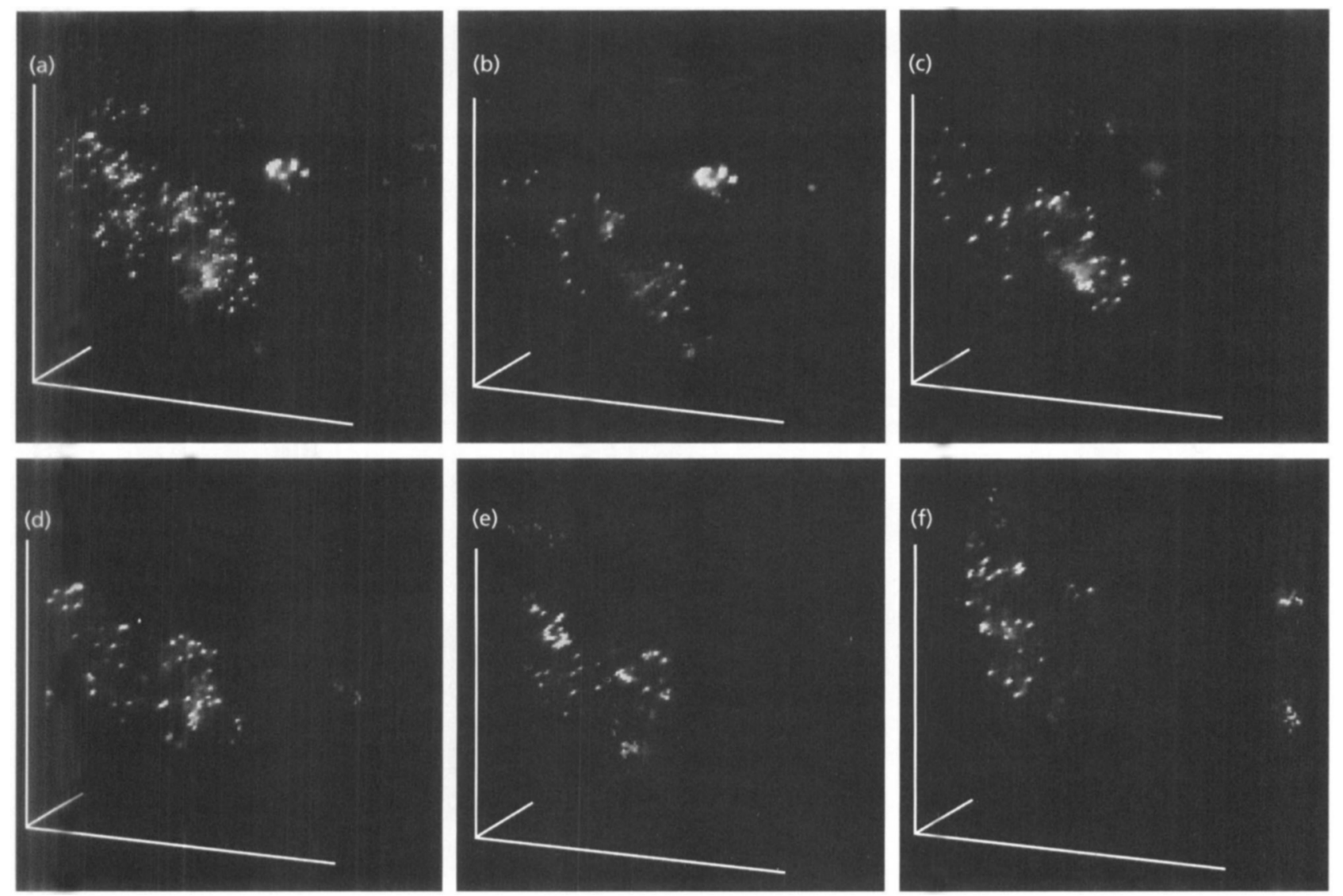

Fig. 6. (a) Three-dimensional CLSM reconstruction of a sludge floc with attached GFP-marked S. marcescens. (b, $c, d, e, f)$ Optical sections in the $z$ dimension of the same floc showing GFP-marked bacteria distributed through the floc volume in cavities and pores. Each of the five sections is $29.9 \mu \mathrm{m}$ in depth.

measured by HIC, was seen for cells that had been exposed to DMSO for $30 \mathrm{~min}$ (data not shown).

\section{CLSM}

Flocs with attached GFP-marked bacteria were optically sectioned using CSLM. Bacteria were distinguishable against the floc background (Figs 6,7). S. marcescens and E. coli showed very different attachment patterns in the flocs. Three-dimensional reconstruction of the flocs revealed that $S$. marcescens attached to the whole floc volume (Fig. 6). Few E. coli cells were found to attach to the flocs; some cells are seen on the outside of the floc in Fig. 7. S. marcescens cells appeared to have access to the interior of the floc through pores and penetrated the floc matrix during the relatively short incubation time. E. coli cells were sometimes seen to move through pores in the floc without attaching, indicating that their larger size, compared to $S$. marcescens, did not exclude them from the floc interior, but that their attachment potential was lower.

\section{DISCUSSION}

The use of GFP-labelled cells enabled us to do direct and detailed studies of attachment of bacterial cells with specific surface characters to activated sludge flocs. $S$. marcescens has a high CSH, probably due to a $70 \mathrm{kDa}$ cell surface protein (Bar-Ness \& Rosenberg, 1989). E. coli 01 is hydrophilic, which may be attributed to its LPS O side-chains and a capsule (Ørskov et al., 1977). Cell surface charges were difficult to assess but did not show large differences between strains or incubation in buffer or in wastewater. The bacteria were chosen as representatives of cells with different CSH but which are otherwise relatively similar; they both belong to the Enterobacteriace, which is a common group in wastewater. Introduction of GFP did not significantly change the $\mathrm{CSH}$ of the test bacteria (Tables 1,2). The difference in surface characteristics between the cells remained when cells were incubated in wastewater compared to PBS, except for a small increase in the hydrophobic subpopulation of E. coli 01 (Table 2, Fig. 2).

A number of other fluorochromes, commonly used for staining of cells [acridine orange, DAPI $\left(4^{\prime}, 6^{\prime}\right.$-diamidino2-phenylindole), TRITC (tetramethylrhodamine isothiocyanate) and CTC (cyano-2,3-ditolyl tetrazolium chloride)] affected the CSH or were difficult to use in the activated sludge (A.-C. Olofsson \& M. Hermansson, unpublished). To the best of our knowledge this is the first report on the use of GFP-marked bacteria and 

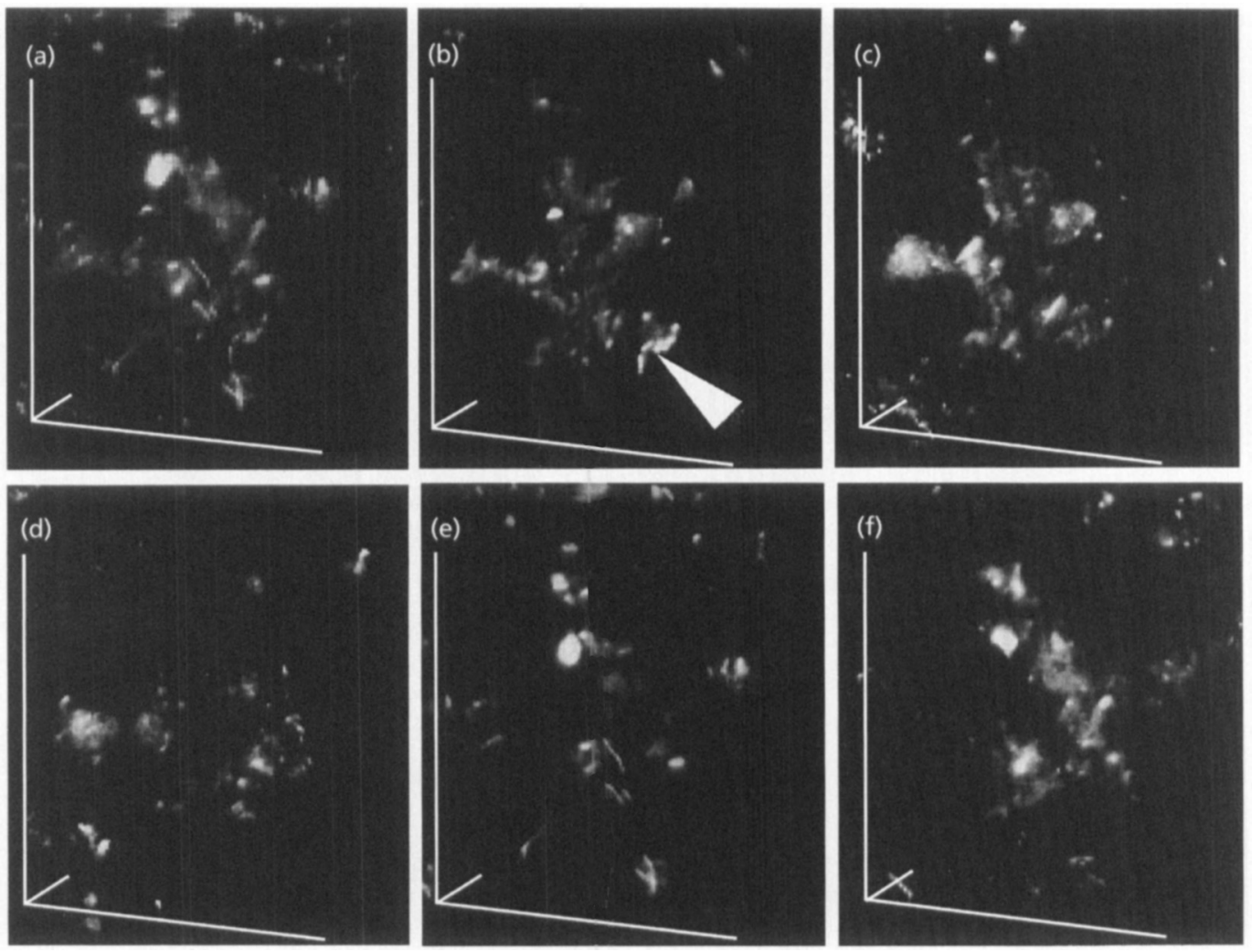

Fig. 7. (a) Three-dimensional CLSM view of a sludge floc with a few attached $E$. coli 01 cells. (b, $c$, d, e, f) Optical sections in the $z$ dimension of the same floc. Each of the five sections is $45 \cdot 2 \mu \mathrm{m}$ in depth. The arrow indicates bacterial cells.

CLSM for specific adhesion studies. It is clear that this combination offers great potential for further investigations. In a recent report by Eberl et al. (1997) GFPmarked $P$. putida were used in survival experiments in activated sludge. Predation of marked bacteria by protozoa was seen after only $2 \mathrm{~min}$. The same observation was made in our experiments where indigested bacterial cells were sometimes seen within predators.

The novel MAC test has been used to determine CSH of bacterial communities in situ (Zita \& Hermansson, 1997a). MAC results correspond well with HIC and BATH values, but give a further complementary characterization of the bacteria on a single-cell level and describe the population in more detail (Fig. 2).

The more hydrophobic $S$. marcescens cells attached in significantly higher numbers to the flocs than the hydrophilic $E$. coli cells on all occasions, despite the fact that sampling was done during different conditions with different flocs (Table 3). The absolute adhesion of both strains varied between sampling occasions, and could not be explained by the floc characteristics (Table 3). The variations show that other factors in addition to the $\mathrm{CSH}$ influenced the partitioning of bacteria between flocs and bulk water. One such factor could be the ionic strength of the wastewater, which was shown to influence bacterial adhesion and floc structure (Zita \& Hermansson, 1994). The shorter half-maximum ad- hesion time for $S$. marcescens may indicate that these cells attach more rapidly, and that a collision between the cell and the floc more often results in adhesion for $S$. marcescens than for E. coli 01 . The results are in general accordance with the thermodynamic approach for describing bacterial adhesion (Absolom et al., 1983). It is interesting that the $\mathrm{CSH}$, as measured by $\mathrm{HIC}$, BATH and MAC, had such a clear effect on adhesion to flocs even though the floc surfaces have a wide range of surface energies, charges, structures, etc.

We have shown previously that hydrophobic bacteria, in general, attach in higher numbers to sludge flocs compared to hydrophilic cells (Zita \& Hermansson, $1997 \mathrm{a}, \mathrm{b})$. In the present investigation we used GFPmarked cells to describe adhesion of hydrophobic and hydrophilic cells to flocs in more detail. To understand the mechanisms of bacterial attachment to flocs it is necessary to distinguish, on a cellular level, between free-living cells and cells associated with small flocs and floc fragments. This is only possible with a microscopical method. The CLSM three-dimensional reconstruction of flocs with attached GFP-marked cells showed a clear difference between the two bacterial species. The much lower numbers of $S$. marcescens in the free-living state compared to $E$. coli were explained by a greater adhesion not only to the outer parts of the flocs (as revealed by conventional fluorescence micro- 
scopy) but also to the interior of the floc. This is evident from Fig. 6 where $S$. marcecens cells are visible in all optical sections of the floc. E. coli 01 was seen in low numbers on the flocs (Fig. 7). Based on physical sectioning of flocs, it has been suggested earlier that there is a water flow through them (Li, 1990). Our findings support this in that the cells rapidly penetrated the flocs and most of the floc volume had attached $S$. marcescens cells.

The surface tensions of the bacterium and the substratum are often lower than the medium $\left(\gamma_{\mathrm{LV}}\right)$, in which case adhesion will be reduced if $\gamma_{L V}$ is decreased due to a reduction of the interfacial energies, $\gamma_{\mathrm{BL}}$ and $\gamma_{\mathrm{SL}}$, which in turn will render $\Delta F^{\text {adh }}$ less negative. Increased DMSO concentrations, which decrease $\gamma_{\mathrm{LV}}$, generally destabilized sludge flocs, except in the incoming water, and also resulted in a lower adhesion of both test bacteria (Figs 3, 5). These results point to the problem with surfactants (which also lower the surface tension of the medium) as pollutants that may decrease the water quality of the effluent both by destabilizing flocs and by decreasing bacterial adhesion to the floc. Polymer addition is a common practice in the operation of many WWTP to increase flocculation. It is interesting from an operational view that the added polymers were also shown to increase adhesion of both hydrophobic and hydrophilic bacteria, thereby reducing free-living bacteria in the effluent water. The increased bacterial adhesion seen after addition of polymers to the wastewater could, however, be reduced by a lowering of $\gamma_{L V}$ (Fig. 5).

In summary, flocculation and sedimentation have direct influence on the quality of the effluent water from wastewater treatment plants. Since cells that remain free-living will escape sedimentation and decrease the quality of the effluent water, it is important to understand the mechanisms for bacterial adhesion to flocs. It is clear from our data that the $\mathrm{CSH}$ can predict the relative adhesion of bacteria in a very heterogeneous system and there is a greater risk that hydrophilic rather than hydrophobic cells escape into the effluent. This was also indicated in a recent investigation on CSH of cells in situ in wastewater that showed that about $80 \%$ of the free-living bacteria in wastewater have a hydrophilic surface (Zita \& Hermansson, 1997a). As judged from our CLSM studies, there is considerable potential for adhesion of hydrophobic bacteria within the floc structure, which would increase the potential of the floc to clear free-living cells from the water. Other factors in addition to $\mathrm{CSH}$ are also important determinants of bacterial adhesion and it is difficult to predict adhesion processes in absolute terms (Table 3). Bacterial adhesion and floc stability are clearly influenced by surface tension of the wastewater and both decreased with a decreasing $\gamma_{\mathrm{LV}}$, which indicates that pollution by various surfactants may have negative effects on flocculation.

\section{ACKNOWLEDGEMENTS}

This project was financially supported by The National Board for Industrial and Technical Development (NUTEK), through the STAMP-consortium in Göteborg and The Foundation for Strategic Research through the Marine Science and Technology (MASTEC) Programme which is gratefully acknowledged.

We would like to thank Professor Søren Molin DTU, Denmark for providing the RP1::gfp plasmid.

\section{REFERENCES}

Absolom, D. R., Lamberti, F. V., Policova, Z., Zingg, W., van Oss, C. J. \& Neumann, A.W. (1983). Surface thermodynamics of bacterial adhesion. Appl Environ Microbiol 46, 90-97.

Andreasen, M. (1997). GFP-marking of marine plasmids. MSc thesis. The Technical University of Denmark.

Ausubel, F. M., Brent, R., Kingston, R. E., Moore, D. D., Seidman, J. G., Smith, J. A. \& Struhl, K. (1989). Current Protocols in Molecular Biology. New York: John Wiley.

Bar-Ness, R. \& Rosenberg, M. (1989). Putative role of a $70 \mathrm{kDa}$ outer-surface protein in promoting cell-surface hydrophobicity of Serratia marcescens RZ. J Gen Microbiol 135, 2277-2281.

Busscher, H. J., Weerkamp, A. H., van der Mei, H. C., van Pelt, A. W. J., de Jong, H. P. \& Arends, J. (1984). Measurement of the surface free energy of bacterial cell surfaces and its relevance for adhesion. Appl Environ Microbiol 48, 980-983.

Chalfie, M., Tu, Y., Euskirchen, G., Ward, W. W. \& Prasher, D. C. (1994). Green fluorescent protein as a marker for gene expression. Science 263, 802-804.

Christensen, B. B., Sternberg, C. \& Molin, S. (1997). Bacterial plasmid conjugation on semi-solid surfaces monitored with the green fluorescent protein (GFP) from Aequorea victoria as a marker. Gene 173, 59-65.

Duncan-Hewitt, W. C. (1990). Nature of the hydrophobic effect. In Microbial Cell Surface Hydrophobicity, pp. 40-73. Edited by R. J. Doyle \& M. Rosenberg. Washington, DC: American Society for Microbiology.

Eberl, L., Schultze, R., Ammendola, A., Geisenberger, O., Erhart, R., Sternberg, C., Molin, S. \& Amann, R. (1997). Use of green fluorescent protein as a marker for ecological studies of activated sludge communities. FEMS Microbiol Lett 149, 77-83.

Eriksson, L., Steen, I. \& Tendaj, M. (1992). Evaluation of sludge properties at an activated sludge plant. Water Sci Technol 25, 251-265.

Forster, C. F. (1971). Activated sludge surfaces in relation to the sludge volume index. Water Res 5, 861-870.

Forster, C. F. \& Dallas-Newton, J. (1980). Activated sludge settlement - some suppositions and suggestions. Water Pollut Control 338-351.

Hermansson, M., Kjelleberg, S., Korhonen, T. \& Stenström, T.-A. (1982). Hydrophobic and electrostatic characterisation of surface structures of bacteria and its relationship to adhesion at an air-water interface. Arch Microbiol 131, 308-312.

Jorand, F., Guicherd, P., Urbain, V., Manem, J. \& Block, J. C. (1994). Hydrophobicity of activated sludge flocs and laboratory grown bacteria. Water Sci Technol 30, 211-218.

Li, D.-h. (1990). Structure of activated sludge flocs. Biotechnol Bioeng 35, 57-65.

Loosdrecht, M. C. M. v., Lyklema, J., Norde, W. \& Zehnder, A. J. B. (1989). Bacterial adhesion: a physicochemical approach. Microb Ecol 17, 1-15.

Marshall, K. C., Stout, R. \& Mitchell, R. (1971). Mechanism of the initial events in the sorption of marine bacteria to surfaces. J Gen Microbiol 68, 337-348. 
Ørskov, I., Ørskov, F., Jann, B. \& Jann, K. (1977). Serology, chemistry, and genetics of $\mathrm{O}$ and $\mathrm{K}$ antigens of Escherichia coli. Bacteriol Rev 41, 667-710.

Rosenberg, M. \& Kjelleberg, S. (1986). Hydrophobic interaction : role in bacterial adhesion. Adv Microb Ecol 9, 353-393.

Stenström, T.-A. \& Kjelleberg, S. (1985). Fimbriae mediated nonspecific adhesion of Salmonella typhimurium to mineral particles. Arch Microbiol 143, 6-10.

Thaveesri, J., Daffonchio, D., Liessens, B., Vandermeren, P. \& Verstraete, W. (1995). Granulation and sludge bed stability in upflow anaerobic sludge bed reactors in relation to surface thermodynamics. Appl Environ Microbiol 61, 3681-3686.

Urbain, V., Block, J. C. \& Manem, J. (1993). Bioflocculation in activated sludge: an analytical approach. Water Res 27, 829-838.

Valin, S. D. \& Sutherland, D. J. (1982). Predicting bioflocculation: new developements in the application of flocculation theory. Environ Technol Lett 3, 363-374.

Zita, A. \& Hermansson, M. (1994). Effects of ionic strength on bacterial adhesion and stability of flocs in a wastewater activated sludge system. Appl Environ Microbiol 60, 3041-3048.

Zita, A. \& Hermansson, M. (1997a). Determination of bacterial cell surface hydrophobicity of single cells in cultures and in wastewater in situ. FEMS Microbiol Lett 152, 299-306.

Zita, A. \& Hermansson, M. (1997b). Effects of bacterial cell surface structures and hydrophobicity on attachment to activated sludge flocs. Appl Environ Microbiol 63, 1168-1170.

Received 16 April 1997; revised 15 October 1997; accepted 27 October 1997. 